\title{
The Spatial Factors and Regional Concentration of Cancer-Related Deaths in Turkey
}

\author{
Türkiye’de Kansere Bağlı Ölümlerin Bölgesel Yoğunlaşması ve Mekansal Faktörler
}

\author{
Fatih ALTUĞํำ, Sevil KILÇIKSIZ²
}

${ }^{1}$ Ondokuz Mayis University, Department of Geography, Samsun, Turkey

${ }^{2}$ Giresun University, Department of Radiation Oncology, Giresun, Turkey

ORCID: F.A. 0000-0001-9163-6116; S.K. 0000-0001-7947-8338

\begin{abstract}
Cancer is the second leading cause of death in the world after cardiovascular disease. Most studies done on cancer in the fields of health geography and epidemiology focus on the spatial distribution of cases. The number of studies addressing the relationship between cancer and spatial factors seems to be low. This study looks at the regional distribution of cancer deaths in Turkey within the context of spatial and environmental factors. The data were obtained from various institutions such as TURKSTAT. We used the coefficients to pin point the number of cancer deaths that occurred in a given location, as well as looking at the environmental and spatial factors behind using global and geographically weighted regression analysis. The data were analyzed both on a national and NUTS Level3 scale. Our results show that the spatial spread of cancer deaths in Turkey and in certain regions is only increasing over time, and that this is exacerbated by factors such as smoking, a lack of prolonged exposure to sunlight, and population density. However, it has been determined that the effects of these factors differ on a regional scale. Our study submits a different perspective to the literature with the findings and different analysis techniques.
\end{abstract}

Keywords: Cancer and space, cancer risk factors, geographically weighted regression

\section{Öz}

Kanser, ölüm nedenleri arasında dünyada kardiyovasküler hastalıklardan sonra ikinci sırada yer almaktadır. Sağlık coğrafyası ve epidemiyolojide kanser ile ilgili çalışmaların odağında vakaların mekânsal dağılışı yer almaktadır. Kanser ile mekansal fakörler arasındaki ilişkiyi ele alan çalışmaların sayısının az olduğu görülmektedir. Bu çalışmada Türkiye'de kansere bağlı ölümlerin bölgesel dağılışı ve bu dağılışa etki eden mekânsal ve çevresel faktörler belirlenmiştir. Veriler başta TÜiK olmak üzere, Tarım ve Orman Bakanlığı, Çevre ve Şehircilik Bakanlığı, Meteoroloji Genel Müdürlüğü gibi çeşitli kurumlardan elde edilmiştir. Çalışmada kanser ölümlerinin bölgesel yoğunlaşması lokasyon katsayısı tekniğiyle çevresel ve mekânsal faktörler küresel ve coğrafi ağırıklandırılmış regresyon analizleri ile belirlenmiştir. Çalışmada çoklu analiz teknikleri kullanılmıştır. Hiyerarşik olarak analizlerin sonuçları birbirlerine entegre edilerek bir sonraki analizin verisi üretilmiştir. Analizler hem ulusal ölçekte hem de NUTS Düzey 3 ölçeğinde yapılmıştır. Bu sayede bölgesel farklılıklar belirlenmiştir. Analiz sonuçları, kanserden ölümlerin Türkiye'de mekânsal yayılımının ve belirli bölgelerde yoğunluğunun zamanla arttığını göstermektedir. Sigara kullanımı, güneşlenme süresi ve nüfus yoğunluğu bu yayılmayı hızlandıran faktörler olarak tespit edilmiştir. Ancak bu faktörlerin etkilerinin bölgesel ölçekte farklılaştığı tespit edilmiştir. Çalışmamız hem elde ettiği bulgular hem de farklı analiz tekniklerini birlikte kullanması yönüyle literature farklı bir bakış açısı getirmektedir.

Anahtar kelimeler: Kanser ve mekan, kanser risk faktörleri, coğrafi ağılıklandırılmış regresyon analizi

Submitted/Başvuru: 26.03.2020 • Revision Requested/Revizyon Talebi: 18.04.2020 • Last Revision Received/Son Revizyon: 19.04 .2020 • Accepted/Kabul: 05.05.2020 Published Online/Online Yayın: 26.11.2020

Corresponding author/Sorumlu yazar: Fatih ALTUĞ / fatih.altug@omu.edu.tr Citation/Atıf: Altug, F., \& Kilciksiz, S. (2020). The spatial factors and regional concentration of cancer-related deaths in Turkey. Cografya Dergisi, 41, 1-12. https://doi.org/10.26650/JGEOG2020-0025 


\section{INTRODUCTION}

According to the World Health Organization, cancer, which is often cited as being the plague of the modern era, is the second most common cause of death after (cardio) vascular disorders; furthermore, the number of cases are only increasing with each passing year. In 2000, 56 million people worldwide were reported to have (12\% of total deaths) died from malignant tumours (WHO, 2008). According to the International Agency for Research on Cancer (IARC), the number of deaths due to cancer and cancer-related complications are showing a dramatic spike. It has been estimated that the number of new cases in 2018 was 18.1 million, or the addition of 9.6 million people compared to the previous year. Experts predict that 43.8 million new cases will emerge within the next 5 years (IARC, 2018). Although death from cancer constitutes approximately $1 / 8$ of all deaths worldwide, this rate is considered to be high when taking into account those who pass away from the indirect effects of cancer (WHO, 2008). Approximately $70 \%$ of these deaths occur in lowand middle-income countries. The economic cost of cancer in 2010 was estimated to be around \$1.16 trillion USD worldwide (IARC, 2018).

The Turkish Statistical Institute (TSI/TÜIK) reports that in 2018, the number of deaths that occurred in Turkey due to cancer ranked second to heart disease, thus constituting $19.4 \%$ of all deaths nationwide (TÜIK, 2018a). According to the WHO (2018), the number of people in 2018 who were diagnosed with cancer was $210,537,56.4 \%$ being men and $43.6 \%$ being women. Again, this number is expected to more than double to 470,851 within the next 5 years (IARC, 2018).

This data in turn shows us that cancer is an important health problem and, that it will continue to be so well into the future. As experts continue to conduct extensive preclinical/clinical research in search of a solution, researchers in fields of health geography and epidemiology are instead focusing their lenses on the spatial distribution of the problem and the factors that influence this.

\section{LITERATURE REVIEW}

To date, health geographers have published a prolific volume of research looking at what environmental factors influence which diseases as well as what impact that has both on health services and on the migration of diseases. Many have also not only examined how changes in environmental factors affects health, but have also investigated the relationship between the development of disease, gender, (Gatrell \& Elliott, 2014; Gesler $\&$ Kearns, 2005) social justice (Rosenberg, 2014) and culture versus health (Gesler \& Kearns, 2005).

For example, Gatrell and Elliott (2014) examined the impact that both air pollution and water resources had on human health, only to conclude that the gasses associated with pollution not only posed a threat to human health in outdoor spaces but also in indoor spaces as well. Curtis and Oven (2012), upon evaluating the effects of global climate change on human health, emphasized that climate change poses various risks on human health. However, in the same breath, they also stated that these risks differ on a regional scale in relation to social and environmental justice factors. Additionally, many health geographers have instead shifted their focus on what and how socio-economic factors impact human health. In this context, Hederos et.al., (2018) emphasize that there is a direct correlation between a person's socio-economic status and the diseases they contract which in turn dictates both their life expectancy alongside the cause of death. Parr (2011) too, stresses the importance of the role that social environment and geographical space play both in psychological as well as physiological diseases.

Such studies tend to view their topic from more of a general and macro angle. Similarly, there too are many studies that only focus their attention on specific diseases. For instance, Páez et.al., (2016) alongside Goovaerts and Goovaerts (2016) have both discussed the spatial distribution and clustering of certain types of cancer. Both of their studies have moreover contributed methodologically to the field of health geography. Weaver (2010) has stated that your physical environment in addition to your health practices both contribute to increasing your risk of developing cancer. In like manner, Hardy and Bugella (2019) have looked at which risk factors play a role in African-American women developing breast cancer by taking such things as race, gender, and age into consideration, and found that one's racial identity stood out as posing a major disadvantage when it came to their fight against the disease. On the other hand, Stuver et. al., (1997) has taken a closer look at the high presence of hepatitis B (HBV) endemia in developing countries in parallel with the geographical distribution of hepatocelluar carcinoma (HCC), and found that there was a striking correlation between $\mathrm{HCC}$ and low socio-economic status, thus concluding that poverty was the sole cause for the spread of both diseases.

Unfortunately, the number of health geographic studies set within a Turkish context remains limited at present. The researches tend to look at what impact various environmental 
factors have on both individual as well as public health (Çalışkan, 2009; Çalışkan \& Sarış, 2008; Yiğit, 2011)

There are few Turkish studies that investigate the correlation between cancer cases and their spatial distribution throughout the country. Özdemir and Özkan have aimed to map cancer across the province of Yozgat. While their efforts proved successful in a descriptive context, they nevertheless had failed to analyze its causality relationship; this in turn meant that their research did not stretch beyond the distribution of cancer cases on a local scale. On the contrary, Taşdemir et al. (2010) examined how often cancer cases occurred in Van province according to gender and organ types. While they did find that malignant tumours occurred more commonly among males, their findings too remained descriptive in nature, and were far from proposing any straightforward causeeffect relationship. In contrast, Çolak and Yomralıoğlu (2007) have analyzed the distribution of cancer cases throughout the province of Trabzon, upon which they used the Turkish National Geographical Information System (GIS / GIS) in order to draw up a cancer density map. What there findings revealed was that both the number as well as type of cases differed according to the class of terrain and elevation level where patients resided. This study differs from other studies in terms of it being a local analysis that looks at cancer cases using GIS.

Beyond regional studies, a small handful of studies that have been conducted on a national scale also exist. Examples of these include one study by Cengiz et. al., (2011) inspecting the distribution of cancer deaths on a national scale in terms of speed, as well as another study (Günay \& Saraç, 2010) which attempted to map cancer out on a national scale.

In summary, the bulk of the research available have descriptively analyzed cancer cases and shown how they are distributed throughout a particular geographic setting. However, it still appears that most remain off the mark in terms of identifying and explaining their causal parameters in relation to that setting. In this context, our study aims both to put forth what spatial determinants exist in relation to cancer-related deaths in Turkey, as well as to statistically explain what causes lie behind those deaths. In order to achieve our aim, we relied on data obtained from secondary sources that focused on cancer-based deaths throughout Turkey in a descriptive context, and then carried on to try and identify which spatial parameters underlie that.

In this respect, we believe that this study will contribute to the literature from two different angles. The first of these is a methodological contribution to the fields of health geography and epidemiology, and in particular, using location coefficient, regression, and geographically weighted regression analysis all within the framework of a single study in order to explain the cases in question, as well as to set ourselves apart in terms of difference of method and technique. The second of these is that we feel that our findings will, more importantly, contribute to national health policies in Turkey. As a results of this study, we propose that policy makers take regional parameters into consideration for each and every cancer case that occurs, and suggest that policy makers consider drafting health policies on a three-tier national, regional, and local scale as part of their approach to top-down health policies.

\section{MATERIAL AND METHODS}

\subsection{Data Set}

The dependent variable of our study is based on the Turkish Statistical Institute's (TSI-TÜİK) data regarding cancer mortality (TÜİK, 2018a). When it came to the data related to the causes of death, we frequently referred to other studies conducted in the fields of health geography and epidemiology (Beale, 2016; Çolak \& Yomralığlu, 2007; Günay \& Saraç, 2010; Güngör, 2013; Hederos et al., 2018).

The TUIK has been regularly publishing data on causes of death in Turkey since 2009. We have chosen to use a panel data set in this study to plot the number of cancer-based deaths that occurred in Turkey from past to present from more of a descriptive angle. Such panels can be used to easily follow the change and progression of a given event across different time periods (Neuman, 2012). In addition, in order for us to be able to compare and contrast any changes in trend that took place in terms of these deaths, we also examined the data cross-sectionally within given slices of time.

Within the scope of this, first we used all of the deaths that occurred between 2009 and 2017 as panel data, all the while paying particular consideration to the Turkish statistical Institute, Economic Region Units Classification (NUTS Level 3), which covers 81 provinces throughout Turkey. Doing this allowed us to better describe spatial and historical development of cancer deaths in Turkey. Secondly, we took cross-sections of the deaths used as dependent variables in the regression analysis and fixed them up to the year 2017 to identify what spatial determinants were behind deaths alongside what their structural characteristics were. However, in order to eliminate any possible misleading 
effects of a single year's worth of data, we drew upon the average of five-years of data spanning between 2013 and 2017. Likewise, we also took into account both the total population of each province and the incidence rates of cancer-related deaths with the aim of eradicating the misleading effect of the number of cases presented in the analysis.

We initiated our research by identifying 20 independent variables, but continued to work with 8 independent variables because we were unable to obtain non-compliance of data periods (i.e. unemployment rate, hope level, average life expectancy) as well as other data (i.e. alcohol consumption, nutrition, obesity) from certain institutions (Table 1). As for the eight variables used in the analysis, they included smoking (i.e. the ratio of the number of cigarette packages sold per province per year to the provincial population), the number of motor vehicles (i.e. the ratio of the total number of motor vehicles to the provincial population), air pollution (i.e. the amount of particulate matter), population density, amount of exposure to sunlight (over a 12 month-average), national income per capital (TL), use of chemical/agricultural fertilizer (da./kg), and pesticide use (da./gr). Among these, we have averaged the variables other than population density and air pollution between 2013 and 2017, and rated each variable with its own unit. in order to determine how many cancer-related deaths occur at a given time ( $\mathrm{t}$ ) and place (i.e. province).

$$
\mathrm{LQ}_{i}^{t}=\left(\mathrm{e}_{i}^{t} / \mathrm{e}_{T}^{t}\right) /\left(\mathrm{E}_{i}^{t} / \mathrm{E}_{T}^{t}\right)
$$

Here, all $t$ values represent time. Hence, $\mathrm{e}_{i}^{t}$ represents the number of deaths caused 'by $\mathrm{i}$ (cancer deaths in the region) for the given region/settlement; $\mathrm{e}_{T}^{t} \mathrm{~T}$ represents the total number of deaths in the given region/settlement; $\mathrm{E}_{i}^{t}$ represents the number of deaths caused by i (cancer deaths in the country) in the country; and $\mathrm{E}_{T}^{t} \mathrm{~T}$ indicates the total number of deaths in the country. LQ is a number between 0 and infinity. A coefficient value of 1 or above means that the case is concentrated in that particular settlement (Şahin \& Altuğ, 2017);

If $\mathrm{LQ}>1, \mathrm{i}$ is concentrated in time $\mathrm{t}$.

If $L Q \leq 1$, the case $i$ is not concentrated within time $t$.

Secondly, we employed regression analysis. In this context, the model that was estimated for the purposes of this research works as follows:

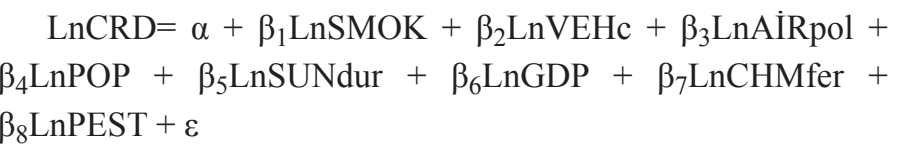

Table 1: Variables used throughout the study.

\begin{tabular}{|c|c|c|}
\hline Variables & Period covered & Data source \\
\hline \multicolumn{3}{|l|}{ Dependent variable } \\
\hline 1. Cancer-related deaths (ratio to population) (CRD) & $(2013-2017)$ & Tüik \\
\hline \multicolumn{3}{|l|}{ Independent variables } \\
\hline 1. Smoking (number of cigarette packs consumed per person) (SMOK) & $(2013-2017)$ & TAPDK \\
\hline 2. Number of motor vehicles (ratio to population) (VEHc) & $(2013-2017)$ & TÜiK \\
\hline 3. Air pollution (amount of particulate matter) (AIRpol) & 2017 & MEU \\
\hline 4. Population density (POP) & 2017 & TÜiK \\
\hline 5. Sunlight Amount of exposure to sunlight (12 month average) (SUNdur) & $1926-2018$ & MGM \\
\hline 6. GDP per capita (TL) (GDP) & $(2013-2017)$ & TüiK \\
\hline 7. Use of chemical/agricultural fertilizer (da./kg) (CHMfer) & $(2013-2017)$ & MAF \\
\hline 8. Pesticide use (da./gr.) (PEST) & $(2013-2017)$ & MAF \\
\hline
\end{tabular}

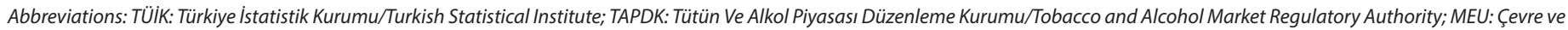

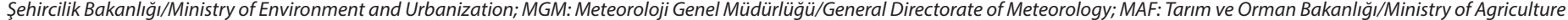
and Forestry

\subsection{Analysis Techniques}

Different analysis techniques were employed throughout this study. First, we used a location coefficient (LQ) to understand what the spatial change was among the deaths. The LQ formula only outlines the degree of condensation of a case, and does not contain any information about the cause of the case's concentration (Altuğ \& Şahin, 2017). You must calculate the LQ
We analyzed this model using IBM SPSS 23 . We opted to use multiple regression as well given that the number of variables was high, albeit upon making a number of assumptions first. In this context, first of all, we ran all of the variables through the normality tests, and observed that some of the data had been irregularly distributed. In order to normalize the variables, we subjected the data to logarithmic transformation, which in turn appeared to resolve this problem for certain variables. Data on 
chemical / agricultural fertilizer and pesticide variants did not have normal distribution. These data were excluded from the analysis because they did not normalize despite different transformation processes. Secondly, we checked to see whether or not there was any autocorrelation among any of the independent variables. Upon performing the correlation analysis using the Durban-Watson and VIF values, we ended up excluding a number of the auto correlated variables from the analysis, including the number of motor vehicles, national income per capita, and air pollution. What remained were variables that influence cancer-related deaths in Turkey.

Thirdly, given that regression analysis or global regression (GR) does not take into account differences in terms of space, (Fotheringham, Brunsdon, \& Charlton, 2002), we transferred the variables to ArcGIS 10.5 and ran them through geographically weighted regression (GWR) analysis with the intent of overcoming this deficiency. Where multiple linear regression analysis generally explains the relationship and significance between the variables,
GWR analysis, on the other hand, shows the changes within independent variables that affect the dependent variable in terms of space, and is used to explain these spatial differences. GWR analysis covers 81 provinces across Turkey on a NUTS Level 3 scale.

\section{FINDINGS}

\subsection{Temporal and Spatial Variation of Cancer-Related Deaths in Turkey}

This section of our study depicts the temporal and spatial variation of cancer deaths in Turkey using the panel data set. Over the 9-year period from 2009 to 2017, the proportion of cancerrelated deaths out of the total number of deaths in Turkey had gradually increased until 2012, and then began to show a partial decline from that point forward (Figure 1). On the other hand, while the ranking of cancer-related mortality in total mortality rates did not change between 2009 and 2012, a downward acceleration in the rates was noticeable after 2012. (Figure 2).

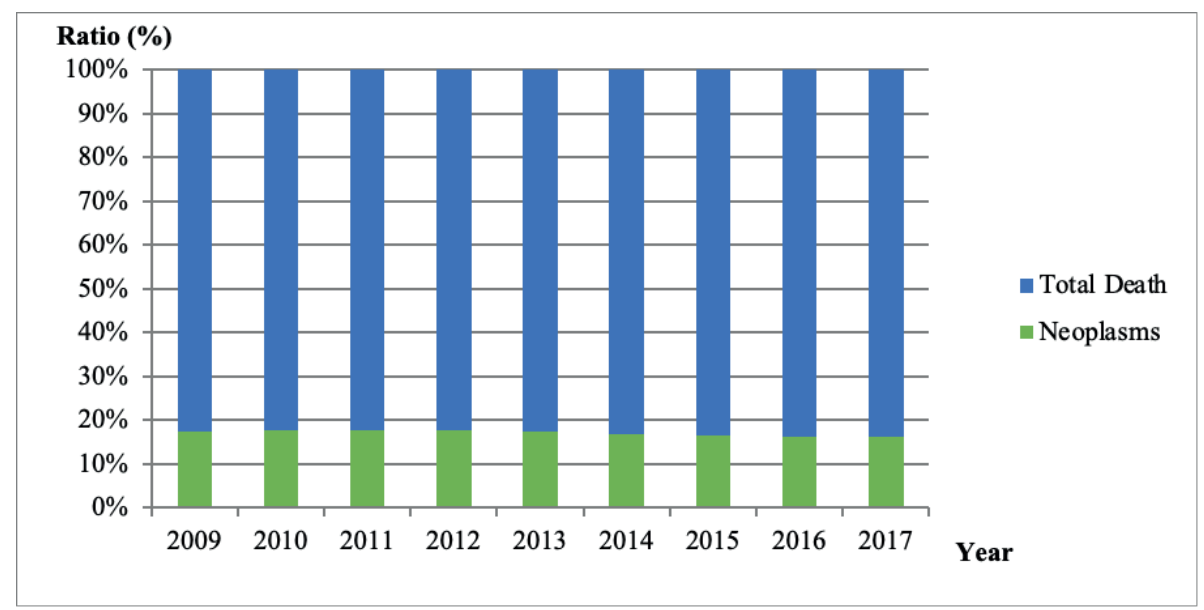

Figure 2: Course of cancer out of total mortality rate (2009 - 2017).

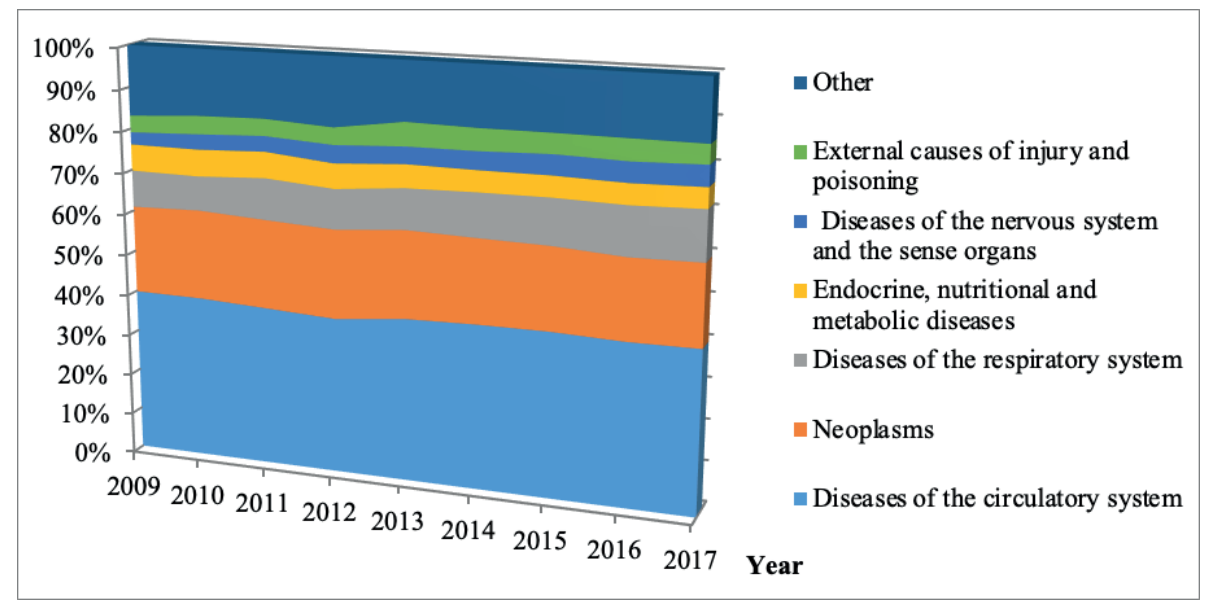

Figure 1: Causes of Death in Turkey (2009 - 2017). 

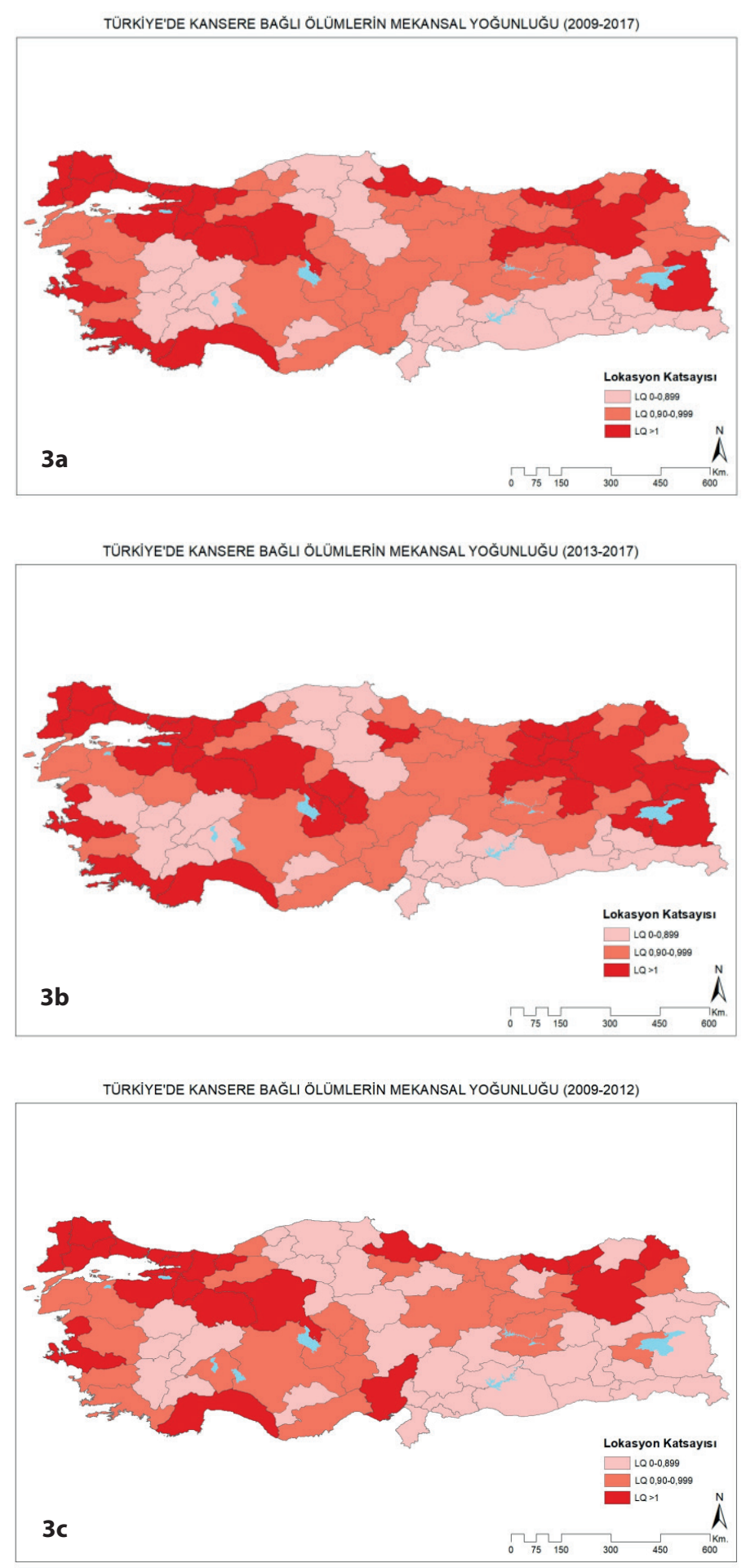

Figure 3: The spatial variation of cancer-related deaths in Turkey.
We set about using the LQ to identify what the spatial concentration was in association with cancer-related deaths. We then transferred these results to the ArcGIS with the aim of revealing the regional concentrations of cancer deaths (Figure 3 ). You can see that the number of such deaths that occurred between 2009 and 2012 are concentrated largely across NorthWestern and-Eastern Turkey (Figure 3a). As this trend continued to intensify in the same regions between 2013 and 2017, we noticed that the case density had spread spatially (Figure $3 \mathbf{b}$ ). We also found that this density was at its lowest peak in SouthEastern Anatolia during both periods. However, when you take a closer look at the regional concentration between 2009 and 2017 (Figure 3c), you will notice that the concentration in the North of the Turkey is, indeed, markedly high.

Two points in particular in the spatial change caught our attention. The first of which is that the number of deaths appear to intensify throughout the provinces of Istanbul, Ankara, Izmir, Bursa, Eskişehir and Kocaeli, all of which are highly industrialized and densely populated. The second is that these numbers also concentrate in the provinces of Erzurum, Erzincan, Trabzon, Rize, Van and Iğdır where both industrialization as well as population density are low in contrast to point one. The factors behind these conditions have been discussed in the preceding sections.

\subsection{The Findings Obtained from the Regression Analysis}

After we made the necessary assumptions in order to perform the regression analysis, we analyzed the variables using the enter method. We in turn found the result of the analysis to be statistically significant at the level of $p<0.000$. That said, we also had excluded some variables from the analysis because the level of significance in the model was above $p>0.005$. Our analysis was then repeated using the remaining 3 variables, thus yielding the final form of the model:

$$
\mathrm{LnCRD}=\alpha+\beta_{1} \mathrm{LnSMOK}+\beta_{2} \mathrm{LnSUNdur}+\beta_{3} \mathrm{LnPOP}+\varepsilon
$$

When you look at the model summary table (Table 2), you can see that the dependent variable explanation rate of the

Table 2: Model Summary Table.

\begin{tabular}{|c|c|c|c|c|c|c|c|c|c|c|}
\hline \multirow{2}{*}{ Model } & \multirow{2}{*}{$\mathbf{R}$} & \multirow{2}{*}{ R Square } & \multirow{2}{*}{$\begin{array}{l}\text { Adjusted R } \\
\text { Square }\end{array}$} & \multirow{2}{*}{$\begin{array}{l}\text { Std. Error of the } \\
\text { estimate }\end{array}$} & \multicolumn{5}{|c|}{ Change Statistics } & \multirow{2}{*}{ - Durbin-Watson } \\
\hline & & & & & R Square Change & F Change & df1 & df2 & Sig. F Change & \\
\hline 1 & $0.887^{a}$ & 0.787 & 0.779 & 0.8643 & 0.787 & 94.934 & 3 & 77 & 0.000 & 1.736 \\
\hline
\end{tabular}

a. Predictors: (Constant), smoking (LnSMOK), amount/length of exposure to sunlight (LnSUN), population density (LnPOP)

b. DependentVariable: Cancer (LnCRD) 
independent variables is $77.9 \%$ (Adjusted R2). In other words, the percentage of deaths caused by cancer in Turkey between 2013 and 2017 is around $77.9 \%$ according to these three variables; the remaining portion can be explained by the other variables that were not included in the analysis. On the other hand, the $F$ value $(F=94.934)$ shows us that the model is significant as a whole ( $\mathrm{Sig}$. $=0.000$ ), whereas the Durbin-Watson test values (Durbin-Watson $=1.736$ ) indicate to us that there is no autocorrelation among any of the variables within the model. The data in the Anova table is also in line with this (Table 3).

Table 3: Anova Table.

\begin{tabular}{|c|c|c|c|c|c|c|}
\hline \multicolumn{2}{|c|}{ Model } & \multirow{2}{*}{$\frac{\text { Sum of Squares }}{2.127}$} & \multirow{2}{*}{$\frac{\mathbf{d f}}{3}$} & \multirow{2}{*}{$\frac{\text { Mean Square }}{0.709}$} & \multirow{2}{*}{$\frac{\mathbf{F}}{94.934}$} & \multirow{2}{*}{$\frac{\text { Sig. }}{0.000^{\mathrm{b}}}$} \\
\hline . & Regression & & & & & \\
\hline & Residual & 0.575 & 77 & 0.007 & & \\
\hline & Total & 2.703 & 80 & & & \\
\hline
\end{tabular}

a. Dependent Variable: Cancer (LnCRD)

a. Predictors: (Constant), smoking (LnSMOK), amount/length of exposure to sunlight (LnSUN), population density (LnPOP)

The coefficients table (Table 4) shows us the values of the parameters obtained from the estimated result predicted by the model. Accordingly, the variable with the highest weight on the dependent variable was smoking $(t=13,073)$. Both population density $(\mathrm{t}=-4.470)$ and the amount/length of exposure to sunlight $(t=-4,987)$ on the dependent variable were close to one another and have a negative effect. The $\mathrm{b}$ coefficient also backs this up. A 1 unit increase in smoking led to an increase in cancer-related deaths by 5.73 units. However, while an increase in population density of 1 unit constituted a 1.33 units increase in the number of cancer cases, a 1 unit increase in the amount of exposure to sunlight led to an 8.28 unit decrease in the number of cancer cases.

\subsection{Findings Obtained from the Geographically Weighted Regression (GWR)}

The variables in the model following regression analysis generally explain the parameters affecting the case. However, the spatial differentiation of these parameters becomes more apparent when we use GWR (Fotheringham et al., 2002; Longley, Goodchild, Maguire, \& Rhind, 2011: 356-360).
Akaike's Information Criterion (AIC) and Adjusted $\mathrm{R}^{2}$ values stemming from the GWR are given in Table 5. The AIC value gives us an idea of how well the model performs, as well as indicates to us that the data in the model overlaps as the value decreases. $\mathrm{R}^{2}$ also indicates to us the model's performance, and has a value between 0 and $100 \%$ (Aydın, Bostan, \& Özgür, 2018). The relationship between the variables increases as $R^{2}$ increases. The residual values indicate the difference between these variables. As the error value increases, the model weakens.

Four models were created during the GWR. While the first model constitutes the analysis of the model in the GR analysis, other models emerged as a result of analyzing each variable in this model individually. Table 5 shows the results of the analysis of the 4 models.

Table 5: GWR analysis table.

\begin{tabular}{lccccc}
\hline Model & Residual Squares & Sigma & AlCc & $\mathbf{R}^{\mathbf{2}}$ & $\mathbf{R}^{\mathbf{2}}$ Adjusted \\
\hline $\mathbf{1}$ & 1.898 & 0.000 & -1156 & 0.818 & 0.769 \\
$\mathbf{2}$ & 3.663 & 0.000 & 1105 & 647 & 604 \\
$\mathbf{3}$ & 1.544 & 0.000 & -1155 & 0.852 & 0.783 \\
$\mathbf{4}$ & 1.596 & 0.000 & -1149 & 0.847 & 0.772 \\
\hline
\end{tabular}

According to the results of the analysis, the AIC values of the models are both low and close to one other; thus meaning that the variables in the model overlap each other. Similarly, the corrected $\mathrm{R}^{2}$ values indicate the level of explanation of the relationship between variables within the models, whereby model 1 is $76.9 \%$, model 2 is $60.4 \%$, model 3 is $78.3 \%$, and model 4 is $77.2 \%$. The similarity between the performance level of model $1(77.9 \%)$ with the GR analysis and the performance level of the GWR (76.9\%) once again proved to us that the reliability of the model was high.

When we examined the maps showing the spatial reflection of the models, we found that the variables carried different levels of significance for each province. Also, when we took a closer look at the map showing Model 1 (Figure 4), we discovered that the standard deviation was $(-0.5 /+0.5)$, and therefore came to the conclusion that the model is significant for those provinces

Table 4: Coefficient results of the regression analysis.

\begin{tabular}{|c|c|c|c|c|c|c|c|c|c|c|}
\hline \multirow[t]{2}{*}{ Model } & \multicolumn{2}{|c|}{$\begin{array}{l}\text { Unstandardized } \\
\text { Coefficients }\end{array}$} & \multirow{2}{*}{$\begin{array}{c}\begin{array}{c}\text { Standardized } \\
\text { Coefficients }\end{array} \\
\text { Beta }\end{array}$} & \multirow[t]{2}{*}{$\mathbf{t}$} & \multirow[t]{2}{*}{ Sig. } & \multicolumn{3}{|c|}{ Correlations } & \multicolumn{2}{|c|}{ Collinearity Statistics } \\
\hline & B & Std. Error & & & & Zero-order & Partial & Part & Tolerance & VIF \\
\hline $1 \quad$ (Constant) & -2.164 & 0.347 & & -6.236 & 0.000 & & & & & \\
\hline Smoking & 0.573 & 0.044 & 0.735 & 13.073 & 0.000 & 0.808 & 0.830 & 0.687 & 0.874 & 1.144 \\
\hline Population density & -0.133 & 0.030 & -0.237 & -4.470 & 0.000 & -0.180 & -0.454 & -0.235 & 0.987 & 1.014 \\
\hline Amount/length of exposure to sunlight & -0.828 & 0.166 & -0.279 & -4.987 & 0.000 & 0.538 & -0.494 & -0.262 & -0.880 & 1.136 \\
\hline
\end{tabular}

a. Dependent variable: Cancer-related deaths 


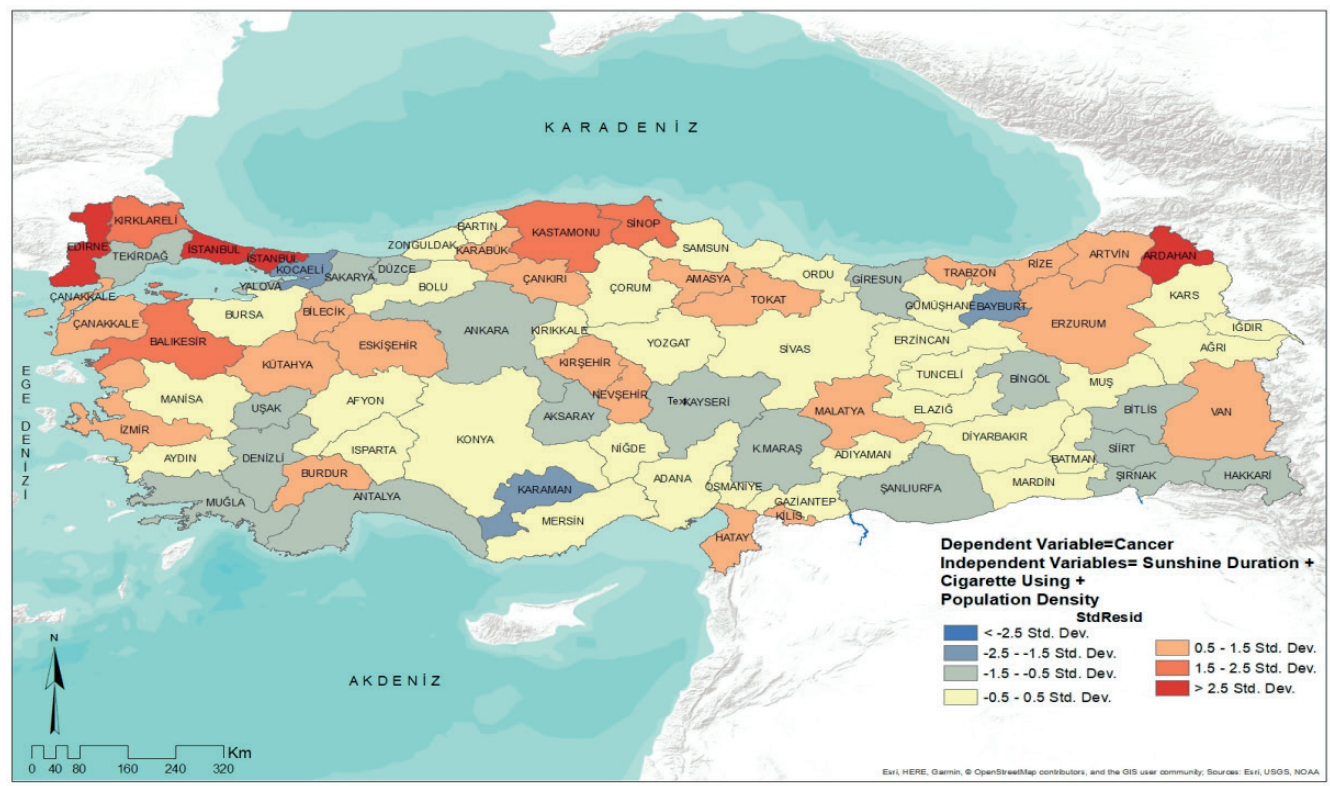

Figure 4: The spatial differentiation of Model 1 based on the GWR.

highlighted in white. Accordingly, you can see that the three variables affecting cancer have more significant relationships in Anatolia's Southern and Eastern provinces.

Upon examining Figure 5, which shows the relationship between cancer-related deaths and the amount/length of exposure to sunlight (model 2), you can see that there were a significantly high number of deaths in regions where the amount of time people spend in sunlight was both either high or low. From this, we can infer that there is dual structure between sunbathing and cancer (Grant, 2007). You also will notice that this model proved to be meaningful for the provinces of Ordu, Trabzon, Rize, Gümüşhane, Bartın, Zonguldak, Düzce, Bolu, and Due to the latitude factor, the sunbathing period of Bursa is lower than the provinces in the South. For this reason, people living in Bursa are exposed to less sunlight which in turn leads to vitamin D deficiency, which is effective in preventing cancer. A lack of vitamin D in humans can therefore increase their risk of developing cancer (Holick, 2013; Freedman, Dosemeci, \& McGlynn, 2002; Garland et al., 2006). In this study, we arrived at the conclusion that the correlation between cancer cases and insufficient exposure to sunlight was statistically significant.

When it comes to Southern Anatolian provinces such as Aydın, Muğla, Mersin, Adana, Kilis, and Diyarbakır, where people are exposed to a high amount of sunlight, you can see that

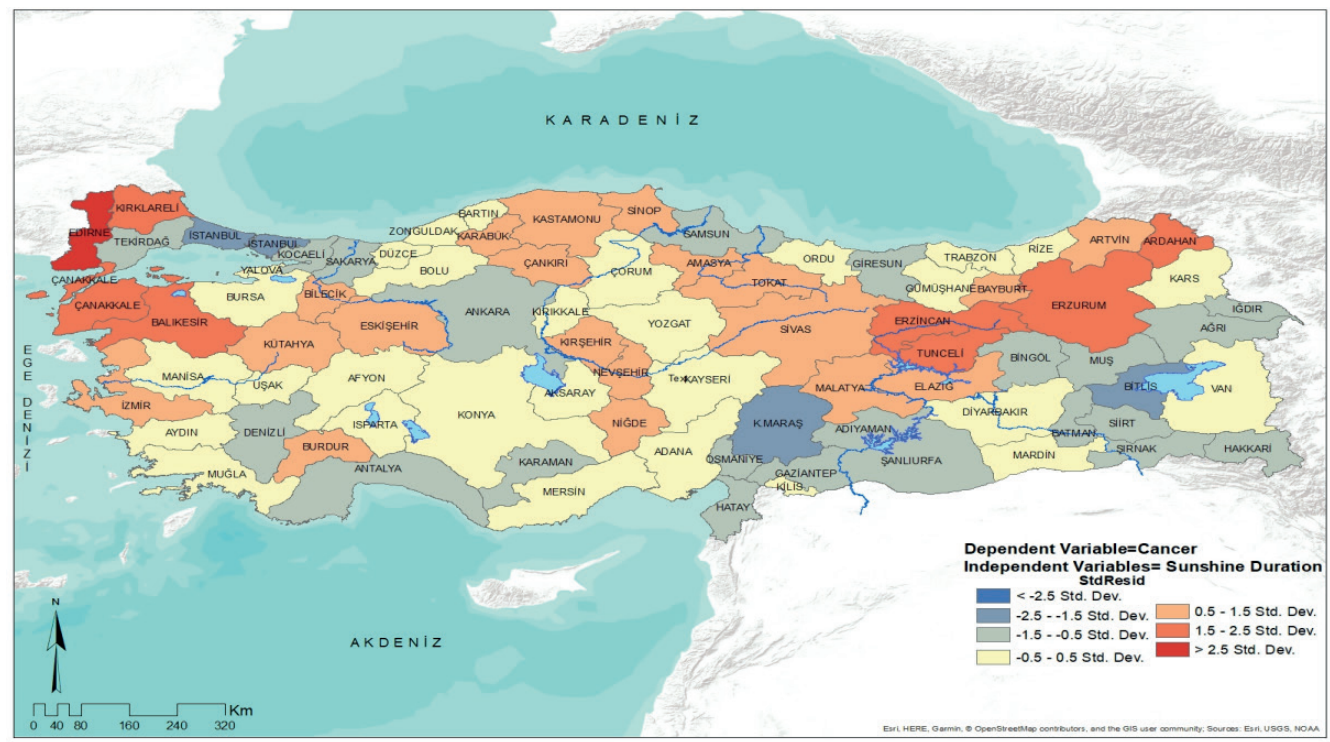

Figure 5: The spatial differentiation of Model 2 based on the GWR. 


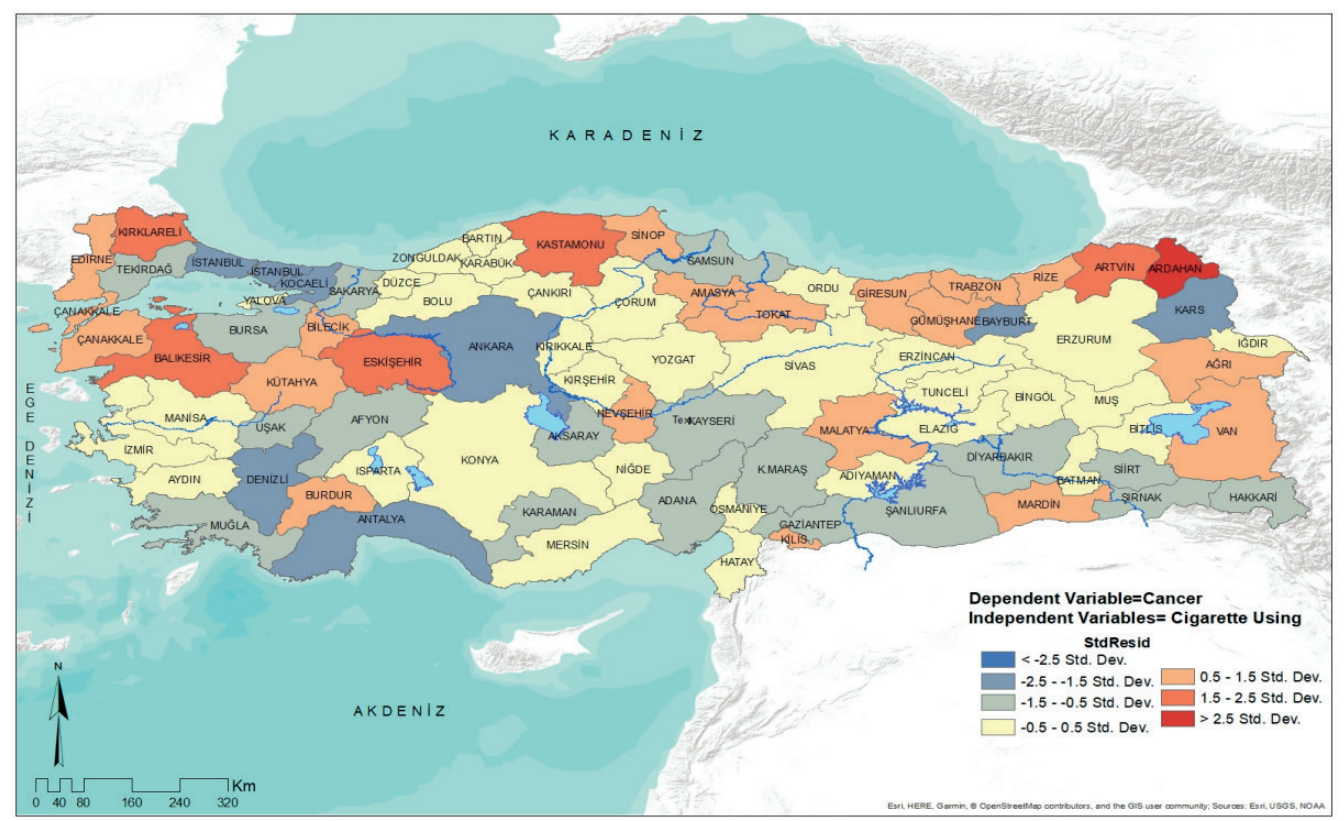

Figure 6: The spatial differentiation of Model 3 based on the GWR.

the model reveals to us there being a significant relationship between sunlight and cancer as well. Considering that these regions are located in Southern latitudes, people are exposed to a significantly high amount of sunlight, and the amount ultraviolet rays (UV) released by the sun comes across as being more intense. This in turn increases people's risk of developing various types of cancer, especially skin cancer (Chen et al., 2013; English, Armstrong, Kricker, \& Fleming, 1997; Grant, 2007).

A closer inspection of Figure 6, which details the correlation between cancer-related deaths and smoking (model 3), reveals to us that the number of deaths tied to smoking is largely concentrated in the provinces of Izmir, Manisa, and Aydin in Western Turkey, as well as in the provinces spanning across central and Eastern Anatolia. We find it to be remarkable that the concentration increases gradually towards the East.

Figure 7, which displays the number of cancer-related deaths in proportion to population density (model 4), shows us that the model varies spatially. We found that the model was more meaningful in the Western-most provinces of Izmir, Aydın, Manisa, and Muğla as well as in the provinces scattered across

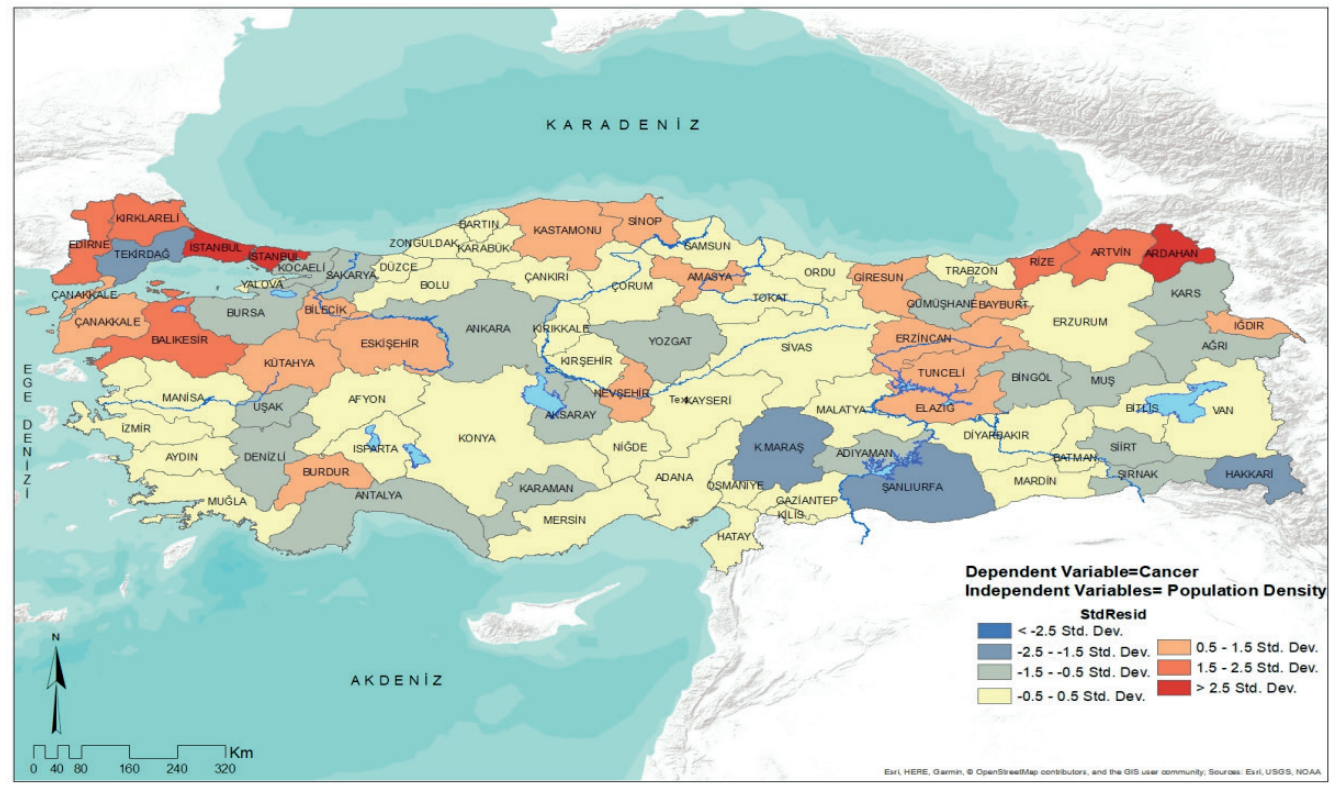

Figure 7: The spatial differentiation of Model. 
Southern and central Anatolia. Nevertheless, the fact that there does not appear to be any significant relationship between the aforementioned provinces versus other provinces with a high population density such as Istanbul, Ankara, Bursa, and Kocaeli means that there are other factors at play.

\section{DISCUSSION}

This study set out to examine cancer-related deaths in Turkey using various complementary analysis techniques. Our findings show us that the spatial spread of death due to cancer across Turkey is only increasing over time in certain regions. After we analyzed our data, we found that smoking, exposure to sunlight, and population density all proved to be factors that accelerated this spread.

The results of the LQ analysis revealed to us that the concentration coefficient of cancer-related deaths was especially high in provinces across Western Turkey, in particular where the population is dense. We found this to also be true in provinces situated throughout North-Eastern Turkey. Numerous studies cite the radioactive aftermath of the nuclear accident at Chernobyl to be at fault for the abnormally high rate of instances of cancer in that region (Türkiye Atom Enerjisi Kurumu-TAEK, 2007a). The regions with the most precipitation during the passage of radioactive clouds after the nuclear accident (Edirne in Thrace and Rize / Findıkl1-Artvin / Hopa in the Eastern Black Sea region) were the areas most affected by radioactivity. Radioactivity measurements taken in these regions show us that the amount of pollution there is well above average (TAEK, 2007b).

One other important finding to emerge from our research includes the statistical explanation of the parameters affecting cancer-related deaths. The results of the regression analysis suggest to us that there is a positive relationship between cancerrelated deaths and smoking. What is more is that this is very much consistent with the literature (Catsburg, Kirsh, Soskolne, Kreiger, \& Rohan, 2014; Gandini et al., 2008; Hecht, 2006; Kuzmickiene et al., 2013; Lynch et al., 2009; Sasco, Secretan, \& Straif, 2004). Likewise, we also discovered that there was a spatial relationship between smoking and cancer cases. Lawmakers could benefit from this finding when it comes to drafting national health policies for regions where the number of cancer deaths due to smoking is particularly high (i.e. Izmir, Aydın, and Manisa, central and eastern Anatolia).

On the contrary, we also discovered that there was a negative correlation between population density and cancer deaths according to our GR analysis; which in turn contradicts with the literature (Chang, Tsai, Chiu, Wu, \& Yang, 2009; Hall et al., 2005; Momenyan et al., 2016; Yang \& Hsieh, 1998). Nevertheless, GWR somewhat curbs this conflict. Given that it is site-sensitive, it has uncovered areas where the relationship between population density and cancer deaths is significant. This negative relationship between the population density and cancer cases emerging from the GR indicates that the variables that have been excluded from it play an effective role in these regions.

A similar situation was found between exposure to sunlight and cancer deaths as well. The amount of time you spend under the sun has a direct relationship both with the amount of vitamin D you internalize alongside the amount of UV light that you are exposed to (Mandelcorn-Monson et al., 2011; Tran et al., 2013). We know that an adequate and optimal exposure to the sun can reduce your risk of developing cancer; we therefore find the results of our GR to be consistent with the literature (Chen et al., 2013; Grant, 2007; Grant \& Garland, 2006). However, based on our findings from the GWR, we observed a much clearer spatial relationship between exposure to sunlight and cancer incidents. In the words of the father of toxicology, Paracelsus (1493 - 1541), "All things are poisons, for there is nothing without poisonous qualities. It is only the dose which makes a thing poison" (Hanekamp, 2008). Hence, in Turkey's Northern most provinces where the amount of sunlight and therefore vitamin D people are exposed to is low, we recommend that vitamin D supplementation be provided as part of preventive healthcare in order to protect the public from developing cancer. On the other hand, in Turkey's Southernmost regions where people are overexposed to high amounts of sunlight, protective measures against $\mathrm{UV}$ radiation is recommended.

\section{CONCLUSION}

This study differs from others in the literature both in terms of its methodology as well as in terms of its technical approach. One limitation of our study was that we did not include certain factors such as obesity and alcohol use, which are known to be linked with cancer, as part of our study due to there being gaps in data records across the country. For this reason, we cautiously interpret part of the results. In spite of that, our employment of more than one analysis technique has granted us the ability to see that there is tremendous regional variation between the parameters associated with cancer death. On a final note, we urge law and policy makers to leave top-down approaches aside and instead take geographical, social, economic and, in particular, regional factors into consideration and to prioritize those factors when drafting national health plans. 
Peer-review: Externally peer-reviewed.

Conflict of Interest: The authors have no conflict of interest to declare.

Grant Support: The authors declared that this study has received no financial support.

Hakem Değerlendirmesi: Dış bağımsız.

Çıkar Çatışması: Yazarlar çıkar çatışması bildirmemiştir.

Finansal Destek: Yazarlar bu çalışma için finansal destek almadığını beyan etmiştir.

\section{REFERENCES/KAYNAKÇA}

Aydın, O., Bostan, P. A., \& Özgür, E. M. (2018). Mekânsal veri analizi teknikleriyle Türkiye'de toplam doğurganlık hızının dağılımı ve modellenmesi. Coğrafya Dergisi(37), 27-45. https://doi. org/10.26650/JGEOG434650

Beale, L. (2016). Effective use of GIS for spatial epidemiology. In Spatial analysis in health geography (pp. 37-52): Routledge.

Catsburg, C., Kirsh, V. A., Soskolne, C. L., Kreiger, N., \& Rohan, T. E. (2014). Active cigarette smoking and the risk of breast cancer: a cohort study. Cancer epidemiology, 38(4), 376-381. https://doi. org/10.1016/j.canep.2014.05.007

Cengiz, M., Koç, H., \& Savaş, N. (2011). Kanser ölüm hızının haritalanması: Türkiye için kesitsel bir araştırma örneği. Erzincan Üniversitesi Fen Bilimleri Enstitüsü Dergisi, 4(2), 197-210.

Chang, C.-C., Tsai, S.-S., Chiu, H.-F., Wu, T.-N., \& Yang, C.-Y. (2009). Traffic air pollution and lung cancer in females in Taiwan: petrol station density as an indicator of disease development. Journal of Toxicology and Environmental Health, Part A, 72(10), 651-657. https://doi.org/10.1080/15287390902733515

Chen, W., Armstrong, B. K., Rahman, B., Zheng, R., Zhang, S., \& Clements, M. (2013). Relationship between cancer survival and ambient ultraviolet B irradiance in China. Cancer Causes \& Control, 24(7), 1323-1330. DOI 10.1007/s10552-013-0210-4

Curtis, S. E., \& Oven, K. J. (2012). Geographies of health and climate change. Progress in Human Geography, 36(5), 654-666. https://doi. org/10.1177/0309132511423350

Çalışkan, V. (2009). Çanakkale ilindeki hayvansal kaynaklı sağlık risklerinin değerlendirilmesi. Uluslararası İnsan Bilimleri Dergisi (Bă̆lantıda), 6(1), 461-486.

Çalışkan, V., \& Sarış, F. (2008). Çanakkale'deki yükseköğretim öğrencilerinin genel sağlık durumlarını etkileyen çevresel faktörlerin araştırılması. Fırat Üniversitesi Sosyal Bilimler Dergisi, 18(1), 43-70.

Çevre ve Şehircilik Bakanlığg (MEU), (2018). Hava kirliliği gözlemleri/ Air pollution observations Retrieved from https://www.havaizleme. gov.tr/.

Çolak, H., \& Yomralıoğlu, T. (2007). Coğrafi bilgi sistemleri ile istatistiksel kanser haritalarının üretilmesi: Trabzon örneği. TMMOB Harita ve Kadastro Mühendisleri Odası 11. Türkiye Harita Bilimsel ve Teknik Kurultayl.

English, D. R., Armstrong, B. K., Kricker, A., \& Fleming, C. (1997). Sunlight and cancer. Cancer causes \& control, 8(3), 271-283. www. jstor.org/stable/3552690
Holick, M. (2013). Vitamin D, sunlight and cancer connection. AntiCancer Agents in Medicinal Chemistry (Formerly Current Medicinal Chemistry-Anti-Cancer Agents), 13(1), 70-82. https:// doi.org/10.2174/187152013804487308

Fotheringham, A. S., Brunsdon, C., \& Charlton, M. (2002). Geographically weighted regression: The analysis of spatially varying relationships. Hoboken: John Wiley \& Sons, Ltd.

Freedman, D., Dosemeci, M., \& McGlynn, K. (2002). Sunlight and mortality from breast, ovarian, colon, prostate, and non-melanoma skin cancer: a composite death certificate based case-control study. Occupational and Environmental Medicine, 59(4), 257-262. http:// dx.doi.org/10.1136/oem.59.4.257

Gandini, S., Botteri, E., Iodice, S., Boniol, M., Lowenfels, A. B., Maisonneuve, P., \& Boyle, P. (2008). Tobacco smoking and cancer: A meta-analysis. International journal of cancer, 122(1), 155-164. https://doi.org/10.1002/ijc.23033

Garland, C. F., Garland, F. C., Gorham, E. D., Lipkin, M., Newmark, H., Mohr, S. B., \& Holick, M. F. (2006). The role of vitamin D in cancer prevention. American journal of public health, 96(2), 252-261. https:// ajph.aphapublications.org/doi/pdfplus/10.2105/ AJPH.2004.045260

Gatrell, A. C., \& Elliott, S. J. (2014). Geographies of health: An introduction: John Wiley \& Sons.

Meteoroloji Genel Müdürlüğü (MGM), (2018). İllerimize Ait Genel istatistik Veriler. Retrieved from https://www.mgm.gov.tr/ veridegerlendirme/il-ve-ilceler-istatistik.aspx?k=A.

Gesler, W. M., \& Kearns, R. A. (2005). Culture/place/health. London \&New York: Routledge.

Goovaerts, P., \& Goovaerts, M. (2016). Space-Time Analysis of LateStage Breast Cancer Incidence in Michigan. In Spatial Analysis in Health Geography (pp. 183-202): Routledge.

Grant, W. B. (2007). Does solar ultraviolet irradiation affect cancer mortality rates in China? Asian Pacific Journal of Cancer Prevention, 8(2), 236. http://journal.waocp.org/article_ 24592 aa18eb7bd9c90a36151ae15c90d0a176.pdf

Grant, W. B., \& Garland, C. F. (2006). The association of solar ultraviolet B (UVB) with reducing risk of cancer: multifactorial ecologic analysis of geographic variation in age-adjusted cancer mortality rates. Anticancer research, 26(4A), 2687-2699. http://ar.iiarjournals. org/content/26/4A/2687.short

Günay, S., \& Saraç, İ. (2010). Kanser Ölüm Oranı Haritaları. Paper presented at the TÜCAUM VI. Coğrafya Sempozyumu Ankara. http://tucaum. ankara.edu.tr/wp-content/uploads/ sites/280/2015/08/semp6_8.pdf

Güngör, H. C. (2013). Epidemiyolojide mekansal analiz Konya ili kanser hastalı̆̆ örneği. Selçuk Üniversitesi Fen Bilimleri Enstitüsü,

Hall, S. A., Kaufman, J. S., Millikan, R. C., Ricketts, T. C., Herman, D., \& Savitz, D. A. (2005). Urbanization and breast cancer incidence in North Carolina, 1995-1999. Annals of epidemiology, 15(10), 796803. https://doi.org/10.1016/j.annepidem.2005.02.006

Hanekamp, J. C. (2008). Micronutrients, hormesis and the aptitude for the maturation of regulation. Am J Pharm \& Toxicol, 3, 144-151. DOI:10.3844/ajptsp.2008.144.151 
Hardy, K., \& Bugella, N. E. (2019). Making Breast Cancer (Black) History: Results of a Church-Based Primary Prevention Study. Social work in public health, 34(3), 251-259. https://doi.org/10.10 80/19371918.2019.1580658

Hecht, S. S. (2006). Cigarette smoking: cancer risks, carcinogens, and mechanisms. Langenbeck's archives of surgery, 391(6), 603-613. DOI 10.1007/s00423-006-0111-z

Hederos, K., Jäntti, M., Lindahl, L., \& Torssander, J. (2018). Trends in life expectancy by income and the role of specific causes of death. Economica, 85(339), 606-625. https://doi.org/10.1111/ecca.12224

IARC. (2018). Latest global cancer data. World Health Organization, Retrieved from https://www.iarc.fr/wp-content/uploads/2018/09/ pr263_E.pdf

Kuzmickiene, I., Everatt, R., Virviciute, D., Tamosiunas, A., Radisauskas, R., Reklaitiene, R., \& Milinaviciene, E. (2013). Smoking and other risk factors for pancreatic cancer: A cohort study in men in Lithuania. Cancer epidemiology, 37(2), 133-139. https:// doi.org/10.1016/j.canep.2012.10.001

Lynch, S. M., Vrieling, A., Lubin, J. H., Kraft, P., Mendelsohn, J. B., Hartge, P., et. al. (2009). Cigarette smoking and pancreatic cancer: a pooled analysis from the pancreatic cancer cohort consortium. American journal of epidemiology, 170(4), 403-413. https://doi. org/10.1093/aje/kwp134

Mandelcorn-Monson, R., Marrett, L., Kricker, A., Armstrong, B. K., Orlow, I., et.al. (2011). Sun exposure, vitamin D receptor polymorphisms FokI and BsmI and risk of multiple primary melanoma. Cancer epidemiology, 35(6), e105-e110. https://doi. org/10.1016/j.canep.2011.03.003

Momenyan, S., Sadeghifar, M., Sarvi, F., Khodadost, M., MosaviJarrahi, A., Ghaffari, M. E., \& Sekhavati, E. (2016). Relationship between urbanization and cancer incidence in Iran using quantile regression. Asian Pacific Journal of Cancer Prevention, 17, 113117. DOI:http://dx.doi.org/10.7314/APJCP.2016.17.S3.113

Neuman, W. L. (2012). Toplumsal Araştırma Yöntemleri Nitel ve Nicel Yaklaşımlar (S. Özge, Trans.). Istanbul: Yayınodası yayıncılık.

Özdemir, Z. T., \& Özkan, E. A. (2016). Yozgat ilinin kanser haritas1 Bozok Tip Dergisi, 6(1), 27-33. http://tipdergisi.bozok.edu.tr/ dosyalar/TipDergisimart2016.pdf\#page $=33$

Páez, A., López-Hernández, F. A., Ortega-García, J. A., \& Ruiz, M. (2016). Clustering and Co-occurrence of Cancer Types: A Comparison of Techniques with an Application to Pediatric Cancer in Murcia, Spain. In P. Kanaroglou \& E. Delmelle (Eds.), Spatial Analysis in Health Geography (pp. 69-90): Routledge.

Parr, H. (2011). Mental health and social space: Towards inclusionary geographies? : John Wiley \& Sons.

Rosenberg, M. (2014). Health geography I: Social justice, idealist theory, health and health care. Progress in Human Geography, 38(3), 466-475. DOI: 10.1177/0309132513498339

Sasco, A., Secretan, M., \& Straif, K. (2004). Tobacco smoking and cancer: a brief review of recent epidemiological evidence. Lung cancer, 45, S3-S9. https://doi.org/10.1016/j.lungcan.2004.07.998
Stuver, S. O., Bosci-Pinto, D., \& Trichopopulos, D. (1997). Infection with hepatitis $\mathrm{B}$ and $\mathrm{C}$ viruses, social class and cancer. IARC Sci Publ., 138, 319-324.

Şahin, M. T., \& Altuğ, F. (2017). Türkiye'de yenilik faaliyetlerinde yenilikçi uzmanlaşma eğilimleri: İstanbul, Ankara ve İzmir bölgeleri imalat sanayi patent göstergeleri. Coğrafi Bilimler Dergisi, 15(2), 157-166. https://doi.org/10.1501/Cogbil_0000000186

Tarım ve Orman Bakanlığı (MAF), (2018). Pestisit ve Kimyasal/ Pesticides and chemical/ Tarımsal Gübre Gübre Kullanımı IstatistikleriAgricultural fertilizer usage statistics. via Post.

Taşdemir, E., Demir, C., Dilek, İ., \& Atmaca, M. (2010). Van ili ve çevresinde malign tümörlerin dağılım sıklığı. Van Tip Dergisi, 17(4), 114-117.

Tran, B., Whiteman, D. C., Webb, P. M., Fritschi, L., Fawcett, J., et. al. (2013). Association between ultraviolet radiation, skin sun sensitivity and risk of pancreatic cancer. Cancer epidemiology, 37(6), 886-892. http://dx.doi.org/10.1016/j.canep.2013.08.013

Türkiye Atom Enerjisi Kurumu (TAEK), (2007a). Çernobil Kazasının Ülkeler Üzerindeki Etkiler. Ankara: Türkiye Atom Enerjisi Kurumu Yayınları.

Türkiye Atom Enerjisi Kurumu (TAEK), (2007b). Türkiye İçin Doz Değerlendirmeleri. Ankara: Türkiye Atom Enerjisi Kurumu Yayınları.

Tütün ve Alkol Piyasası düzenleme Kurumu (TAPDK), (2019). Cigarette Sales Amounts by Province. Retrieved from https://www. tarimorman.gov.tr/ TADB/Menu/22/Tutun-Ve-Tutun-MamulleriDaire-Baskanligi.

Türkiye İstatistik Kurumu, (TÜİK), (2018a). Ölüm Nedenleri İstatistikleri. Retrieved from http://www.turkstat.gov.tr/PreTablo. do?alt_id=1083.

Türkiye İstatistik Kurumu, (TÜİK), (2018b). Gelir, Yaşam, Tüketim ve Yoksulluk İstatistikleri. Retrieved from http://www.turkstat.gov.tr/ UstMenu.do?metod=kategorist.

Türkiye İstatistik Kurumu, (TÜİK), (2018c). Nüfus ve Demoğrafi İstatistikleri. Retrieved from http://www.turkstat.gov.tr/UstMenu. do?metod=kategorist.

Türkiye İstatistik Kurumu, (TÜİK), (2018d). Ulaşım ve İletişim İstatistikleri. Retrieved from http://www.turkstat.gov.tr/PreTablo. do?alt_id=1083.

Weaver, H. N. (2010). Native Americans and cancer risks: Moving toward multifaceted solutions. Social work in public health, 25(34), 272-285. https://doi.org/10.1080/ 19371910903240621

WHO. (2008). World Cancer Report. Lyon: World Health Organization Yang, C. Y., \& Hsieh, Y. L. (1998). The relationship between population density and cancer mortality in Taiwan. Japanese journal of cancer research, 89(4), 355-360. https://doi.org/10.1111/j.1349-7006.1998. tb00571.x

Yiğit, G. K. (2011). Türkiye'de sağlık coğrafyası çalışmaları üzerine Nature Sciences, 6(1), 30-41. https://dergipark.org.tr/en/download/ article-file/111999 